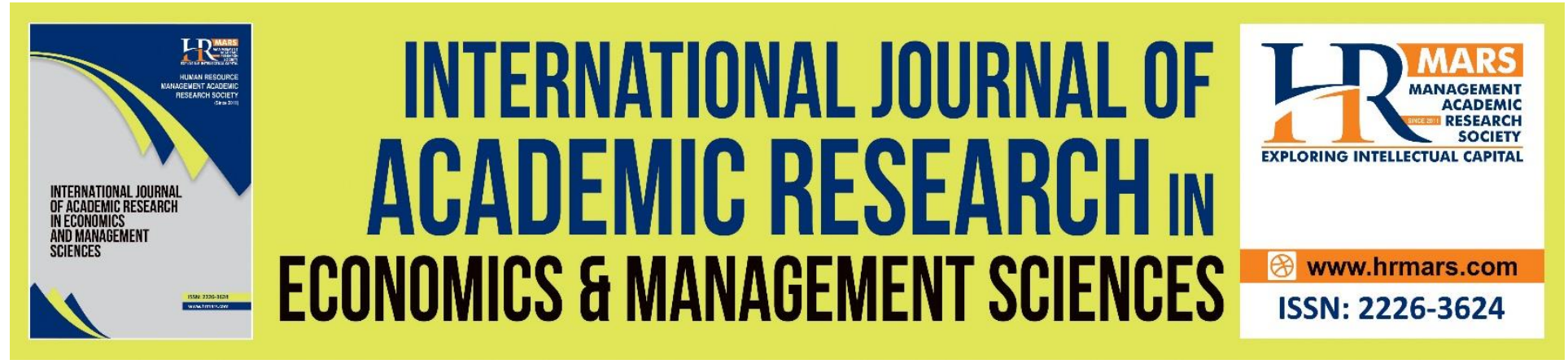

\title{
Reliable Dimensions of Ergonomic Work System in the Malaysian Manufacturing Industries
}

\author{
Mohd Nasir Selamat, Noremy Md Akhir, Siti Fardaniah Abdul Aziz, Amar \\ Hisham Jaaffar \& Rogis Baker
}

To Link this Article: http://dx.doi.org/10.6007/IJAREMS/v9-i2/7878

DOI: $10.6007 /$ IJAREMS/v9-i2/7878

Received: 29 March 2020, Revised: 27 April 2020, Accepted: 25 May 2020

Published Online: 26 June 2019

In-Text Citation: (Selamat, et al., 2020)

To Cite this Article: Selamat, M. N., Akhir, N. M., Abdul Aziz, S. F., Jaaffar, A. H., \& Baker, R. (2020). Reliable Dimensions of Ergonomic Work System in the Malaysian Manufacturing Industries. International Journal of Academic Research in Economics \& Management Sciences. 9(2), 102-112.

Copyright: (c) 2020 The Author(s)

Published by Human Resource Management Academic Research Society (www.hrmars.com)

This article is published under the Creative Commons Attribution (CC BY 4.0) license. Anyone may reproduce, distribute, translate and create derivative works of this article (for both commercial and non-commercial purposes), subject to full attribution to the original publication and authors. The full terms of this license may be seen

at: http://creativecommons.org/licences/by/4.0/legalcode

Vol. 9, No. 2, 2020, Pg. 102 - 112

http://hrmars.com/index.php/pages/detail/IJAREMS

JOURNAL HOMEPAGE

Full Terms \& Conditions of access and use can be found at http://hrmars.com/index.php/pages/detail/publication-ethics 


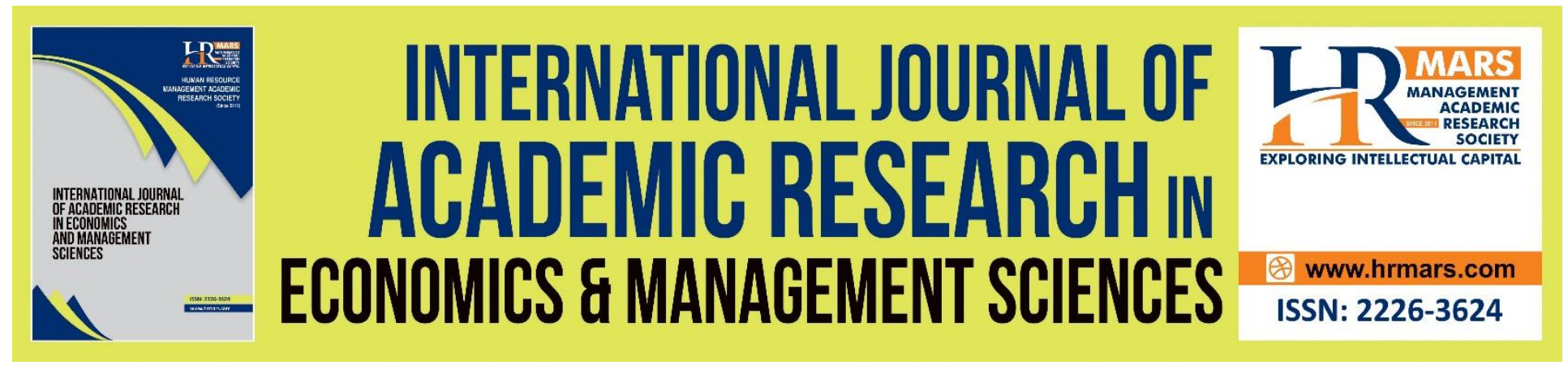

\title{
Reliable Dimensions of Ergonomic Work System in the Malaysian Manufacturing Industries
}

\author{
${ }^{1}$ Mohd Nasir Selamat, ${ }^{1}$ Noremy Md Akhir, ${ }^{1}$ Siti Fardaniah Abdul \\ Aziz, ${ }^{2}$ Amar Hisham Jaaffar \& ${ }^{3}$ Rogis Baker
}

${ }^{1}$ Centre for Research in Psychology and Human Well-being, Faculty of Social Sciences and Humanities, Universiti Kebangsaan Malaysia, Malaysia, ${ }^{2}$ Department of Management and Human, Resources, College of Business Management and Accounting, Universiti Tenaga Nasional Malaysia, Malaysia, ${ }^{3}$ Department of Defence Human Resource Management National Defence University of Malaysia, Malaysia.

Email: noremy@ukm.edu.my

\begin{abstract}
Manufacturing sector has its own unique system of work that demonstrates the needs on ergonomics aspect improvement. Hence, this study aimed to evaluate the elements of Ergonomic Work Systems (EWS) that is expected to have impact on workers' performance. Seven hundred ninety respondents from several manufacturing industries in Malaysia were involved in this study. A quantitative method with non-experimental study was used in this study, while Statistical Package for Social Sciences (SPSS) version 25 was used to analyse the data. Findings showed that most of the workers were not aware of issues related to ergonomics at work. The study also found that all items asked in the instrument could measure each EWS variable with acceptable value of Cronbach Alpha. Significantly, findings show that improvement for ergonomic-related campaign in workplaces is the key initiative for manufacturing sector's sustainability that in line with the global industrial revolution.
\end{abstract}

Keywords: Employee, Ergonomic Work System (EWS), Ergonomics, Manufacturing Industry, Malaysia, Safety and Health, Human Resource Management

\section{Introduction}

According to the Department of Statistics Malaysia (2015), the manufacturing sector has been one of the biggest contributors to the country's economic growth until 2015. The manufacturing sector is one of the highest performing sectors. This has proven that manufacturing sector is one of the sectors that provide ample employment opportunities to Malaysians. Therefore, it can be concluded that manufacturing sector is one of the most important contribution sectors for the country's economy.

In Malaysia, previous study find that only about $20 \%$ of Malaysian workers are aware of ergonomic aspects (Selamat, 2016). Lack of awareness of these ergonomic aspects will lead to 
employee performance issues as well as occupational safety and health issues. According to Makhbul, Abdullah and Hashim (2013), and Selamat and Mukapit (2018), most countries have low levels of ergonomic applications and ergonomic awareness despite the fact that the impact of these ergonomics has significant impact particularly on employee performance and occupational safety and health. Conceptually, worker problems are often associated with factors in the ergonomic work system. Good ergonomic work systems are said to affect job safety and health (Selamat \& Aziz, 2017).

According to a report released by the Malaysia Social Security Organization (SOCSO), the number of employment accident reported in 2017 increased from a total of 66,618 cases to 69,980 cases compared with 2016 . The report also shows that the manufacturing sector has the highest number of accidents compared to the major economic sectors in 2017. In addition, according to a newspaper report in 2015 named The New Strait Times, study shows that $47 \%$ of workers in Malaysia were exposed to risks and dangers in the workplace. This report shows that manufacturing sector is one of the highest sectors exposed to hazards. These risks expose workers to a range of problems such as physical health, workplace accidents, emotional problems, work absence, and psychosocial problems (Niu, 2010). The Department of Occupational Safety \& Health (DOSH) reported that each year, the payment of compensation for accidents in Malaysia was extremely high at RM1.2 billion (DOSH, 2010). This figure involved more than 55,000 accident cases with more than 1,000 of fatal accidents in the manufacturing industry (DOSH, 2010).

While various efforts have been made to address the problem of occupational accidents, the increasing number of cases continues to be an alarming rate in Malaysia. According to Carayon, Xie and Kianfar (2014) in order to ensure the safety and health aspects of employment in manufacturing sector, precaution to maintain good workplace condition and ergonomic aspects should be given attention. This is because the ergonomic aspect will provide more space and flexibility for employees within the work environment.

\section{Background \& Objective of Study}

In short, ergonomic terms are defined as the relationship between humans and machines or the environment that generally refers to the physical environment at work. The term is synonym with human factors which is a field of study that involves the role of psychologists and engineers in the effort to produce products or systems that are easy to use, safe, to maximize efficiency and to minimize physical and psychological stress (Aamodt, 2016).

Ergonomics deals with an application of knowledge about human behaviour, capabilities, and limitations to the design of systems, machines, tools, tasks or jobs and environments for the uses of human in a constructive, safe, and effective way (Carayon, 2009; Shikdar, Al-Araimi \& Omurtag, 2002). Others defined ergonomics as the science of designing the job to fit the worker, instead of forcing the worker to fit the job (Smith \& Carayon, 2000; Rowan \& Wright, 1994; Makhbul, 2009). In addition, the Chairman of the National Institute of Safety and Health of Malaysia (NIOSH), Tan Sri Lee Lam Thye, pointed out that ergonomics refers to the science and technology that enables user- friendly tools for work, design, and workplace environment that meet the physical and psychological requirements of workers (Harian, 2008).

Insufficient ergonomic aspects can lead to negative effects such as job stress, overwork, health problems such as bone pain and joints, thus affecting the performance of employees and 
organizations. Poor ergonomics design with lack of training and participation from others, such as social support will increase workers' chances of being stressed and sick (Pickup, Nugent \& Bowie, 2019). For example, an organization's whose employees are highly committed and participate on the ergonomics issues are more likely to have a stable, productive and safe workforce, which avoid them from involved stress (Lowe, Schellenberg \& Shannon, 2003; Matthews, Gallus \& Henning, 2011). This in turn, will decrease the likelihood of accidents in the workplace, as well as reducing absenteeism rates that would eventually increase workers' performance (Selamat, 2016).

Hence, for the current study, factors of ergonomic work system is focussed on individual, task-, technology-, organizational-, and environmental-factor. These elements are in line with suggested Work System Model by Smith and Sainfort (1989) and the Theory of Balance by Smith and Carayon (2000) which discussed the need of those elements to be addressed in an organization especially in the manufacturing industry. The Work System Model explains elements of work that affect workers and outcomes; in which, Smith and Carayon (1989) explain that tasks performed by individuals who use tools and technologies (machines and equipment) is determined by the physical environment and organizational conditions. Therefore, the dimensions of the work system model will interact with each other to produce a good individual performance.

Further, individual factors are the involvement of individual needs, individual skills, individual experiences and psychosocial characteristics, cognitive characteristics and physical characteristics (Selamat, 2016). In addition, workload, the control of work and autonomy, the content and challenges of work and the ability to learn, job contents, opportunities, challenges, and task significance are all considered to be individual elements in a work system (Selamat, 2016).

Furthermore, organizational factors mean involvement in organizational participation, reward and recognition as well as social and organizational support (Selamat, 2016). Social and organizational support, participation, teamwork, training programs, work schedules, incentives, as well as job security form the focus in work system elements (Carayon, 2009). Therefore, an understanding of such work system elements will assist workers in doing well in their jobs, and lead to a more successful organization.

In addition, the factor of machinery and equipment is the involvement of the design aspects of equipment and technology, the use of equipment and technology, and the design of work stations (Selamat, 2016). The design and usability of tools and technologies, as well as the workstation design, are seen as elements in these factors. Appropriately, designed machinery and equipment facilitate employees in performing the duties, and better ensure the safety of employees (Selamat, 2016). This could be referred to the size and layout of chairs, tables and desks, and other equipment or furniture.

Environmental factors could be referred to the physical environment within the organization. Carayon (2009) indicates that the physical environment refers to elements such as workspace design, layout of the workplace, noise, lighting, climate, humidity, vibration, and others. Moreover, Carayon (2009) also mentioned that the work system model does not provide specific guidance about job design and redesign. Therefore, the work system model is complemented by a series of design principles that are at the core of Balance theory. The main reasons behind the development of Balance Theory were to improve workers' quality of working 
life, stress, and the physical and mental health of workers (Carayon, 2009; Smith and Sainfort, 1989).

The emerging similarity concept between work system and ergonomics could be explained in the Work System Model by Smith and Sainfort (1989) and the Theory of Balance by Smith and Carayon (2000). Hence, the development concept of Ergonomic Work System (EWS) in the current study is conveying the same objective of work system and ergonomics at workplace. Therefore, the purpose of current study is to identify the element of EWS that enhance workers' performance in manufacturing industry of Malaysia.

\section{Methodology}

According to Bryman and Bell (2007), a chosen research design reflects the focus of a study, shows the causal connections between variables, generalizes with regard to larger groups of individuals than those actually forming part of the investigation, and makes it easy to understand behaviour in specific social context. Therefore, this study adopted the descriptive study approach, offering a profile, or a description, of relevant aspects of the phenomena of interest to the researcher from the perspective of individual self-report.

This study also based on a quantitative research approach. The quantitative method is considered as non-experimental research in nature, and has been used in many fields of study, especially in the area of social science (Chua, 2006). This study also used probability sampling, which refers to those populations that have a known opportunity of being chosen as subjects in the sample (Sekaran, 2000). To be specific, the current study was conducted using stratified random sampling that assists in estimating the population parameters and identifying the subgroup of elements within the workers at the manufacturing industries.

Surveys are conducted using questionnaires aimed at measuring the characteristics, experiences, knowledge and opinions of a sample or population. The study involved industries or organizations in the manufacturing sector in several states in Malaysia including Selangor, Negeri Sembilan, Johor, Kedah, Perak, Perlis, Pahang and Kelantan. The production operators in the manufacturing sectors were selected as respondents from different sub-sectors. This is because, these workers involved in various work activities and surrounding environment that has its own unique work and tasks. These production operators were involved extensively in physical tasks including the use of machines with safety problem risks in the manufacturing industries.

A set of questionnaires was created to determine the element of EWS at the manufacturing industry. Moreover, this study adapted certain approaches to suit the context of the study. This means that several elements from others studies were utilized to assist in measuring variables in the current study. Furthermore, the five-point Likert scale was used to measure every item in the questionnaire. The items were translated into Malay language since it is the national language of Malaysia; respondents were expected to be proficient with the language. The developed questionnaire was also tested in a pilot study before the actual study is conducted and has acceptable level of reliability. Based on Table 1, the Cronbach's alpha for each dimension showed that majority has a high reliability above 0.70 . Data were analysed according to the needs of the study using the Statistical Package for Social Sciences (SPSS) version 25. 


\section{Results}

Seven hundred ninety out of 1000 sets of questionnaires were returned from various organizations (79\% return rate). Some of answered questionnaires were unusable due to incomplete answers, such as respondents failed to fill in the items consistently, and it is found that more than five items were not filled in the questionnaire as required. Hence, the incomplete questionnaires were not included in the final analysis.

Table 1 shows the profiles of the respondents. Out of the total respondents, 445 were male participants $(56.3 \%)$, while female participants were $345(43.7 \%)$. Further, in terms of respondent's age, the respondents were categorized into five sections namely 17 years to 27 years, 28 years to 37 years, 38 years to 47 years, 48 years to 57 years and finally 57 years and above. The respondents in this study were mostly 17 to 27 years old $(29.2 \%)$, followed by the 28th-37th (29.8\%), 38 to 47 year olds 138 (17.5\%)., 48 to 57 years old were 58 people (7.5\%) and the least were respondents aged 57 and above who were 7 (7.5\%).

The respondents of this study are divided into four marital status including single, married, divorced and widowed. The single respondents represented 330 (41.8\%). The married status was represented by $428(54.2 \%)$, while the divorced were 6 people who represented (0.8\%). Finally, the categories of widowed were 26 (3.3\%). There were three main classified races in Malaysia including Malays, Chinese and Indians ethnic. Malay ethnic were highest participated in this study with a total of $629(79.6 \%)$ followed by the Chinese ethnic as 91 people (11.5\%), Indian ethnic were 66 people (8.4\%) and other nations, as many as 4 people $(0.5 \%)$.

In addition, this study also determined the duration of service in the companies (manufacturing industries). The survey found that 432 people (54.5\%) of the respondents had served for less than 5 years, 189 (23.9\%) of the respondents had served 5 to 10 years, while 66 $(8.4 \%)$ of the respondents had served 11 to 15 years of service. Moreover, the respondents that served 15 to 20 years were 48 people (6.1\%) and only 7 respondents (1\%) served 21 years and above.

In terms of education levels, this study has listed seven (7) categories of academic qualification including Bachelor or higher, Diploma, School of Management (MCE / SPM), Secondary, Primary, Elementary, Professional / Technical Certificate and Others. Findings indicated that majority of the respondents or $118(14.9 \%)$ had an academic degree at the Bachelor level or higher, followed by 232 (29.4\%) of the respondents with academic degree at the Diploma level. A total of 355 (44.9\%) respondents had academic approval at the Secondary level; respondents with academic at the level of Primary School were 11 (1.4\%). Finally, 45 respondents or $5.7 \%$ had Professional or Technical Certificate and others were $7(0.9 \%)$. 
INTERNATIONAL JOURNAL OF ACADEMIC RESEARCH ECONOMICS AND MANAGEMENT SCIENCES Vol. 9, No. 2, 2020, E-ISSN: 2226-3624 @ 2020 HRMARS

Table 1: Profile of the Respondents

\begin{tabular}{|c|c|c|c|}
\hline Domain & Items & Frequency & Percentage (\%) \\
\hline \multirow[t]{5}{*}{ Age } & $17-27$ years & 295 & 37.2 \\
\hline & 28-37 years & 292 & 36.8 \\
\hline & $38-47$ years & 138 & 17.5 \\
\hline & $48-57$ years & 58 & 7.5 \\
\hline & 57 an above & 7 & 7.5 \\
\hline \multirow[t]{2}{*}{ Gender } & Male & 445 & 56.3 \\
\hline & Women & 345 & 43.7 \\
\hline \multirow[t]{4}{*}{ Marital Status } & Single & 330 & 41.8 \\
\hline & Married & 428 & 54.2 \\
\hline & Divorce & 6 & .8 \\
\hline & Widow & 26 & 3.3 \\
\hline \multirow[t]{4}{*}{ Ethnic Group } & Malay & 629 & 79.6 \\
\hline & Chinese & 91 & 11.5 \\
\hline & Indian & 66 & 8.4 \\
\hline & Others & 4 & .5 \\
\hline \multicolumn{4}{|l|}{ Service Duration } \\
\hline & Less than 5 years & 432 & 54.5 \\
\hline & $5-10$ years & 189 & 23.9 \\
\hline & $11-15$ years & 66 & 8.4 \\
\hline & $15-20$ years & 48 & 6.1 \\
\hline & 21 an above & 7 & 1.0 \\
\hline \multirow[t]{7}{*}{ Education Level } & Bachelor Degree and above & 118 & 14.9 \\
\hline & Diploma & 232 & 29.4 \\
\hline & $\begin{array}{l}\text { Secondary School (Upper) } \\
\text { (MCE/SPM) }\end{array}$ & 355 & 44.9 \\
\hline & Secondary School (Lower) & 22 & 2.8 \\
\hline & Primary School & 11 & 1.4 \\
\hline & Professional Certificate & 45 & 5.7 \\
\hline & Others & 7 & 0.9 \\
\hline
\end{tabular}

Table 2 shows the results of Cronbach's alpha coefficient reliability analysis according to the study dimensions. The overall alpha Cronbach value was greater than 0.70 . The highest alpha Cronbach was 0.891 for machine and tools factors, followed by 0.823 for organizational factor, task factor with $0.719,0.763$ for the ergonomic environmental factor.

Table 2 Cronbach Alpha Value

\begin{tabular}{lcc}
\hline \multicolumn{1}{c}{ Dimensions } & N Items & A Cronbach \\
\hline Occupational Accident & 3 & 0.498 \\
Task Factor & 18 & 0.719 \\
Organization Factor & 17 & 0.823 \\
Ergonomic Environment Factor & 11 & 0.763 \\
Machine and Tools Factors & 15 & 0.891 \\
\hline
\end{tabular}


Table 3 shows a descriptive analysis of all the variables associated with this study. For the task factor shows a minimum of 18 , a maximum of 81 , and a mean of 57.0241 and a standard deviation of 8.90184. In addition, organizational factors indicate a minimum of 17 , a maximum of 81 , and a mean of 55.0203 and a standard deviation of 9.74085 . The environmental factors showed a minimum value of 11 , a maximum of 88 , a mean of 40.2051 and a standard deviation of 6.70024. Finally, the machine and tool factors showed a minimum value of 15 , a maximum of 75 , and a mean of 54.6013 and a standard deviation of 9.34804 .

Table 3 Descriptive result of the variables

\begin{tabular}{lccccc}
\hline Item & $\mathbf{N}$ & Minimum & Maximum & Mean & Std. Deviation \\
\hline Task Factor & 790 & 18.00 & 81.00 & 57.0241 & 8.90184 \\
Organization Factor & 790 & 17.00 & 81.00 & 55.0203 & 9.74085 \\
$\begin{array}{l}\text { Ergonomic } \\
\text { Environment Factor }\end{array}$ & 790 & 11.00 & 88.00 & 40.2051 & 6.70024 \\
$\begin{array}{l}\text { Machine and Tools } \\
\text { Factors }\end{array}$ & 790 & 15.00 & 75.00 & 54.6013 & 9.34804 \\
\hline
\end{tabular}

\section{Discussion}

The study aimed to evaluate the measurement of EWS elements and provide insights to organizations, industry practitioners, researchers in ergonomics, occupational safety and health and related parties while providing awareness and useful inputs to face the challenges of the world industrial revolution. Hence, aspects of ergonomic work system including the knowledge, implementation, and improvement of this ergonomic aspect at work should be investigated. Findings indicated that several dimensions of ergonomic work system are reliable dimensions including individual-(occupational accident), task-, organization-, ergonomic environment-, and machine and tools-factor. These dimensions can be used as ergonomic implementation. This is consistent with research by Nasir, Ismail, Daud and Ismail (2016) which found the design of furniture contribute to ergonomics aspects of safety and health among entrepreneurs in Kelantan, Malaysia. Meanwhile, Deros, Mohd, Mohamad and Indah (2016) found that manual handling activities and tasks that were not designed ergonomically will caused back pain among workers in the Malaysian oil palm industry. In addition, ergonomic implementation is very important because it takes into account human factors. This is in line with the needs of the Theory of Balance by Smith and Carayon (2000) who emphasized the importance of ergonomic elements in work as they can contribute to job safety and health. Meanwhile, Selamat (2016) had mentioned ergonomics implementation will lead to: (a) increased productivity, (b) improved health and safety of workers, (c) lower worker compensation claims, (d) compliance with government regulation (e.g. OSHA standards), (e) job satisfaction, (f) increased work quality, (g) lower worker turnover, (h) less lost time at work, (i) improved morale of workers, and (j) decrease in absenteeism rates. In addition, many studies had confirmed that the implementation of effective and robust ergonomic systems will positively impact on the development of workers and organizations, especially in terms of occupational safety and health (Rodovalho, Hajj, Marcio \& Tomi, 2019; Spasojevic Brkic, Klarin, \& Brki, 2015; Selamat et al., 2019; Selamat \& Mukapit, 2018; Makhbul et., 2013). Therefore, the elements of the Ergonomic Work Systems (EWS) need to be understood and practiced properly to increase workers' performance. 
Further, the EWS is crucial as Vinothini, Leonard and Omar (2015) stressed the needs of ergonomics intervention through work organization solution. Consistently, Sulaiman, Kosman, and Ja'afar (2016) argued the needs of formal learning to improve EWS through appropriate training and educational program, in which, workplace safety and health can be improved by matching the right skills of using equipment to accomplish work tasks. Aziz and Osman (2019) also supported to improve workers' safety and health by suggesting to organize compulsory training for workers as intervention for EWS. In fact, Mahboobi, Taghipour and Azadeh (2020) had proven that most ergonomic risks can be reduced by providing the right knowledge, skills and experience to improve workers' safety and health.

\section{Conclusion}

This study was organized using sample in manufacturing industries in Malaysia. It examined the element of Ergonomic Work Systems (EWS) that can enhance workers performance. The study focused on five element EWS including individual factors, task factors, machine and tools (technology) factors, organizational factors and ergonomic environment factors. All the five elements shows significant measurement of EWS in the manufacturing industries and be used to determine the workers performance especially on aspects related to safety and health, workplace layout and design, task and workload, and the work environment.

The EWS elements have gone through several processes of analysis that confirmed it were reliable dimensions to enhance ergonomics aspects in organization. This study also developed from the Balance Theory of theoretical view (work system model and work balance theory), specifically regarding safety at work, which is reflected on worker's performance. Findings from empirical data support the dimension in the conceptual framework of EWS towards workers performance.

The study also benefited to provide an understanding of practical implementations of ergonomics in the workplace in a Malaysian context. Introducing a EWS would contribute greatly to the safety of those employees with direct involvement in safety and health risks, and would help academicians, organizations and policy makers to improve performance at work.

The study also provides guidance to responsible parties in improving the safety and health performance and related issues of human resource aspect at workplace. It can also be used as guide in drafting policies and laws related to occupational safety and health priority to the government. These policies and regulations could be complied with by manufacturing industries in Malaysia. In fact, changes related to the implementation of EWS are needed to ensure future problems of occupational safety and health aspect. This will lead to improved health quality among workers as well as better organizational performance.

\section{Acknowledgements}

Special thanks to the Universiti Kebangsaan Malaysia that supported the writing of this article under Geran Galakan Penyelidik Muda (GGPM-2017-067). 
INTERNATIONAL JOURNAL OF ACADEMIC RESEARCH ECONOMICS AND MANAGEMENT SCIENCES

Vol. 9, No. 2, 2020, E-ISSN: 2226-3624 @ 2020 HRMARS

\section{References}

Aamodt, M. G. (2016). Industrial/Organizational Psychology: An Applied Approach. USA: Cengage Learning.

Shikdar, A., Al-Araimi, S., \& Omurtag, B. (2002). Development of a software package for ergonomic assessment of manufacturing industry. Computer \& Industrial Engineering Journal, 43, 485-493.

Aziz, S. F. A., \& Osman, F. (2019). Does compulsory training improve occupational safety and health implementation? The case of Malaysian. Safety Science, 111, 205-212.

Harian, B. (2008). Keselamatan di tempat kerja. Retrieved online, from https://www.bharian.com.my/

Bryman, A., \& Bell, E. (2007). Business Research Methods, 2nd Ed. New York: Oxford University Press Inc.

Carayon, P. (2009). The Balance Theory and the Work System Model... Twenty years later. International Journal of Human-Computer Interaction, 25(5), 313-327.

Carayon, P., Xie, A., \& Kianfar, S. (2014). Human factors and ergonomics as a patient safety practice. BMJ Quality Safety, 23, 196-205.

Chua, Y. P. (2006). Kaedah penyelidikan; Buku 1. Mc Graw Hill, Kuala Lumpur, Malaysia.

Deros, B. M., Mohd, H. A., Mohamad, D., \& Indah, D. D. D. (2016). Ergonomic risk assessment on oil palm industry workers. Iranian Journal of Public Health, Vol. 45, Suppl. Issue No. 1, Feb 2016, pp.44-51.

Rodovalho, E. D. C., Hajj, T. M. E., Marcio S., \& Tomi, P. G. D. (2019). New ergonomic device to improve occupational safety of blasthole drill operators. Journal of Materials Research and Technology. 8, 2, 1712-1719.

Lowe, G. S., Schellenberg, G., \& Shannon, H. S. (2003). Correlates of employees' perceptions of a healthy work environment. America Journal Health Promotion, 17, 390-399.

Mahboobi, M., Taghipour, M., \& Azadeh, M. (2020). Assessing ergonomic risk factors using combined data envelopment analysis and conventional methods for an auto parts manufacturer. Work, (Preprint), 1-16.

Matthews, R. A., Gallus, J. A., \& Henning, R. A. (2011). Participatory Ergonomics: Development of an Employee Assessment Questionnaire. Accident Analysis and Prevention, 43, 360369.

Nasir, A. H. B. A., Ismail, A. R. B., Daud, K. A. M., \& Ismail, S. (2016). Design specifications of ergonomic sofa through sofa makers perception: A case study in Malaysia. Malaysian Journal of Public Health Medicine, 16(Supplement 2), 27-35.

Niu, S. (2010). Ergonomics and Occupational Safety and Health : An ILO Perspective. Applied Ergonomics, 41, 744 - 753.

Pickup, L. Nugent, B., Bowie, P. (2019). A preliminary ergonomic analysis of the MRI work system environment: Implications and recommendations for safety and design. Radiography. 25, 4. 339-345.

Rowan, M. P., \& Wright P. C. (1994). Ergonomic is good for business. Work Study, 43(8), 7-12. MCB University Press.

Sekaran, U. (2010). Research methods for business: A Skill-building Approach, (5rd ed). USA: John Wiley and Sons, Inc. 
Selamat, M. N. (2016). Ergonomic work system and occupational safety and health performance: Mediating effect of psychosocial work factor. Unpublished Doctor of Philosophy Dissertation, Penang, Universiti Sains Malaysia.

Selamat, M. N., \& Mukapit, M. (2018). The Relationship Between Task Factors \& Occupational Safety and Health (OSH) performance in the printing industry. Akademika, 88(3), 65-76. ISI ESCI Indexed.

Selamat, M. N. (2013). 139 The determinant of OSH performance: A study on ergonomic work system. Occupational and Environmental Medicine, 70(Suppl 1), A47-A47.

Selamat, M. N., Mukapit, M., Aziz, S. F. A., \& Makhbul, Z. M. (2019). Re-definition of Occupational Safety and Health Performance in Malaysian Manufacturing Industry. International Journal of Recent Technology and Engineering (IJRTE) ISSN: 2277-3878, 8, 2 S10.

Smith, M. J., \& Carayon, P. S. (2000). Work organization and ergonomics. Applied Ergonomics 31: 649-662.

Smith, M. J., \& Sainfort, P. C. (1989). A balance theory of job design for stress reduction. International journal of industrial ergonomics, 4(1), 67-79.

Sulaiman, M. K. A. M., Kosman, A. K. \& Ja'afar, N. H. (2016). An assessment of students' understanding on anthropometry and ergonomic in shelter design execution. Journal of Engineering Science and Technology, Special Issue on PEKA 2016, November (2016) 40 - 52.

Spasojevic Brkic, V. K., Klarin, M. M., \& Brki, A. D. (2015). Ergonomic design of crane cabin interior: The path to improved safety. Safety Science, 73, 43-51.

Vinothini, P., Leonard, H. J., \& Omar, B. (2015). Ergonomics intervention through work organization solution: The way forward. Applied Ergonomics, (46), 231.

Makhbul, Z. M., Abdullah, N. L., \& Hashim, N. A. (2013). Stres di tempat kerja: isu global dalam melestarikan organisasi. Journal of Social Sciences and Humanities, 8(1), 41 - 59.

Makhbul, Z. M. (2009). Persepsi Organisasi Multinasional di Malaysia Terhadap Pengurusan Stesen Kerja Ergonomik. Journal of Social Sciences and Humanities, 4(1), 137-146. 